\title{
The Determination of the Action towards the Patient's Psychological Therapy in the Post-accident Using Case-based Reasoning
}

\author{
Sri Mulyana*1, Ilham Sahputra ${ }^{2}$
}

${ }^{1}$ Departement of Computer Science and Electronics, FMIPA UGM, Yogyakarta

${ }^{2}$ Department of Informatics Engineering, Faculty of Engineering, Malikussaleh University e-mail : ${ }^{* 1}$ smulyana@ugm.ac.id, ${ }^{2}$ ilham.sahputra@unimal.ac.id

\section{Abstrak}

Kecelakaan yang menimpa seseorang akan meninggalkan derita yang sangat mendalam, apalagi jika mengakibatkan cedera berat seperti patah tulang yang memerlukan penanganan serius. Pasien tidak hanya membutuhkan tindakan yang berkaitan dengan cedera yang dialaminya, namun juga memerlukan therapi psikologis untuk menghadapi masalah tersebut oleh psikolog. Salah satu metode penalaran dalam sistem pakar adalah penalaran berbasis kasus (Case-Based Reasoning). Pada penalaran berbasis kasus (Case-Based Reasoning), suatu basis kasus berisi kasus-kasus dengan kondisi atau gejala-gejala dan solusi (therapi psikologis) yang diberikan. Untuk menemukan solusi dari sebuah kasus baru yang diberikan, sistem akan mencari kasus-kasus dalam basis kasus yang memiliki tingkat kesamaan antar kasus yang paling tinggi.

Pada penelitian ini telah dikembangkan Sistem Penalaran Berbasis Kasus untuk Penentuan Tindakan therapi psikologis bagi pasien pasca kecelakaan yang memerlukan penanganan serius. Therapi psikologis tersebut meliputi asistensi, konsultasi, dukungan psikiater maupun gabungan dari beberapa tindakan tersebut. Basis kasus dibangun berdasarkan catatan penanganan psikologis rumah sakit 'Dr. Soeharso' di Surakarta.

Berdasarkan hasil dari Sistem Penalaran yang dikembangkan, telah berhasil ditentukan tindakan therapi psikologis dari pasien berdasarkan kondisi atau gejala yang dialami. Hasil tersebut diperoleh dengan menghitung tingkat similaritas antara masalah baru dengan seluruh kasus yang ada dalam basis kasus. Therapi psikologi pada kasus yang memiliki similaritas paling tinggi dan telah memenuhi batas threshold yang ditentukan akan direkomendasikan untuk menangani pasien dengan kondisi yang diinputkan. Sistem CBR pada penelitian ini berhasil mencapai akurasi 60\% dengan batas threshold 50\%.

Kata kunci-Case Based Reasoning, therapi psikologis, tingkat kesamaan kasus

\section{Abstract}

The accident that occurred to somebody will give much suffering; moreover, if the accident gives the serious injury, such as a broken bone which needs to get more serious treatment. Not only does the patient need the action towards the injury, but also the psychological therapy is needed in facing the problems occured which is suggested by a psychologist. One of the reasoning methods in expert systems is Case-Based Reasoning (CBR). In the Case-Based Reasoning system, a case-based consists of various cases in conditions or symptoms and solutions. To find out the solution from a new problem given, the system will find any cases in the case-based which have higher degree of similarity among the cases.

This research develops a case-based reasoning system to decide the action of the psychological therapy towards the patients in the post-accident who needs serious treatment. The psychological therapy cosists of giving assistance, consultation, psychiatrist support, and the compound of various actions as well. A case study was conducted from the medical records of psychological treatment at 'Dr Soeharso' hospital in Surakarta.

Based on the result of the research developed, the action of psychological therapy upon the patient has successfully determined. Our CBR system reaches accuracy rates of $60 \%$ in the threshold 50\% compared to the treatments resulted from the psychologist. The result was found by calculating the degree of similarity between the new issue and all cases existing in the case base.

Keywords - Case Based Reasoning, psychological therapy, similarity of cases 


\section{INTRODUCTION}

The CBR has been one of the methods from the knowledge-based systems in many domains. CBR method uses the preliminary case solution to solve the new problem. The fundamental framework of Case-Based Reasoning is the assumption of similar case which has the similar solution.

CBR consists of four main phases, they are:

1. Retrieve : It is re-taking (retrieving) the same case. In this phase, it will process the finding or calculating from any similar cases.

2. Reuse: It is re-using information and knowledge in that case to solve the new problem. In this phase, it will find the solution from the same case at the previous condition.

3. Revise : It is revising the solution given. In this step, finding out the solution from the same case in the previous condition into the present case will occur then.

4. Retain : It is retaining a part of the previous experience in order to be used in solving the next case.

The relationship between the four steps above will display below.

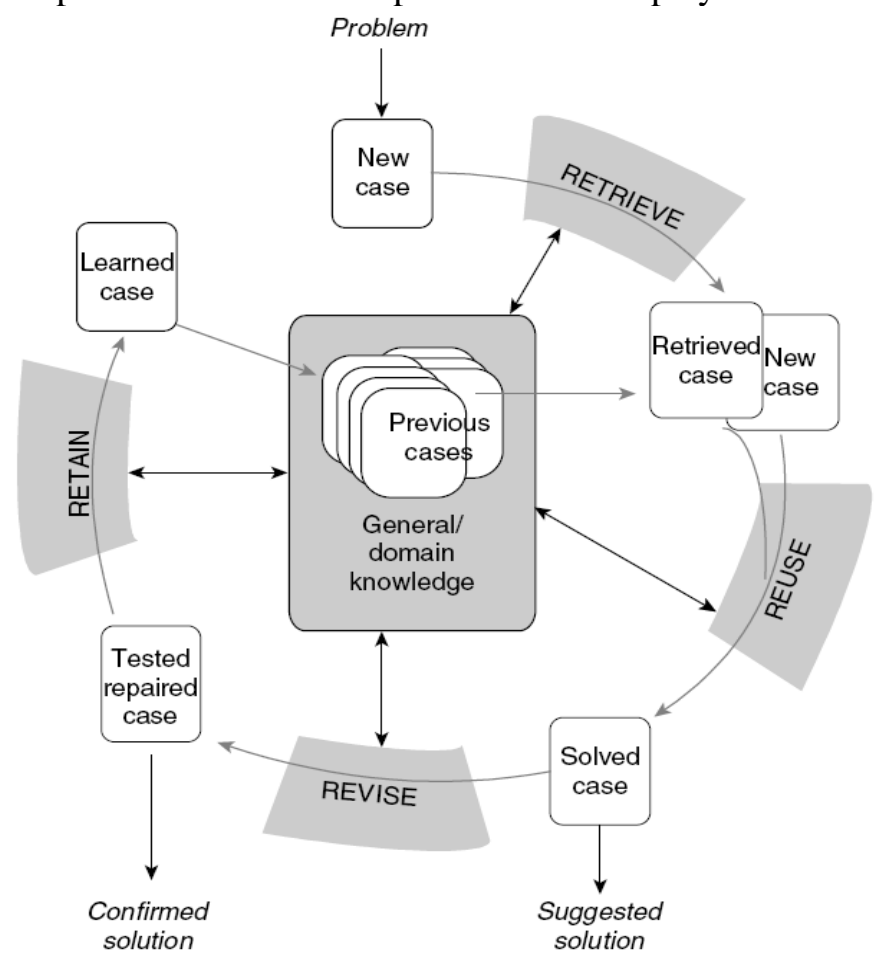

Figure-1: the cycle of Case-based Reasoning [1]

The application of CBR method has been developed significantly in any fields particularly in health. One of them is CBR to diagnose any diseases from infection [2]. In that research described that a case has attributes: temperature, dizziness symptoms which include its intensity and area, cough, the intensity of pass water, getting vomit and urinating. All of those attributes are numeric from 1 to 4 to describe the degree of intensity, such as never, low, middle and high. The aforementioned research used the formula of Euclidean distance to calculate the degree of case similarities. The CBR system has also been developed to detect Swine Flu Diagnostic Assistant. [3], and to diagnose the heart attack [4]. In the field of neurology has been developed CBR system which was called by NDS (Neurology Diagnosis System) [5]. CBR system has also been developed to promote some mass campaigns in warning to quit smoking.

IJCCS Vol. 12, No. 1, January 2018: $11-20$ 
That system is consisted of the early warning on the dangerous smoking which was sent by cellular phone [6]. CBR system has also been developed to detect the disturbance of feeling $(\operatorname{mood}[a f e k t i f])[7]$ and to diagnose the heart attack [8] and selecting study program in senior hight school [9]. In future, CBR system may be able to provide the better service in the medical field and it may also give more integrated in clinical environment.

In doing daily activities, somebody often gets the more complicated problem, so that he needs the guidance or convenience from the psychologist, and also for somebody who get the serious injury. Besides, he needs a special treatment from his injury that he got, and he also needs the guidance from a psychologist to get the psychological therapy.

Based on the operational and procedural standard, all actions which relate to treating patients as the psychological therapy may be recorded in good medical record of patient. However, the medical record of patient has not been used effectively, particularly in developing science. Therefore, it is essential to use a mutual co-operation between the interest holders to develop the progress of the science its self. The medical record of patient in hospital is the collection of cases, which contain the condition, symptoms that is conducted by a doctor and therapy for its treatment. The medical record of patient can be the source of any case- bases particularly in a case-based computerized reasoning.

On the other hands, the psychological expert has a limit of time, a bunch of emotion or the consistency of delivering in solving problems. So that, it needs the development of mastering system to sole that limits. By using various cases had been occurred before, afterwards it can be developed by a mastering system as it is found in Case Based Reasoning, and it remains considering the existence of some similarities in solving cases.

\section{METHODS}

This research will develop a Case-Based Reasoning Systems to determine the psychological therapy for patients in post-accident who get injury, and then he needs the role of psychologist. In order to get the aims, so the researchers conduct several phases, as it follows:

1. Data Collection

In this phase, the researchers collected some data which contain the action of the psychological therapy, worked together with orthopedic of emergency unit of "Dr. Suharso" hospital in Surakarta. This step is the most important and strategically step.

2. Verification of case-based findings

In this phase, the researchers conduct various consults with the experts of psychology in order to find the mark that the base case generates the valid and well-enough to develop CBR systems.

3. Implementation

In this phase, the CBR systems has been developed to determine the psychological therapy for the patients in post-accident. The more prior duty can be conducted in CBR system is calculating the level of similarity between new problem with the all cases on the casebased, and then selecting the case from the case-based which have the higher threshold, as the recommendation of the psychological therapy.

Whereas, the general description from the determination of the action of the psychological therapy for patients in post-accident by using CBR system is displayed in Figure 2. 


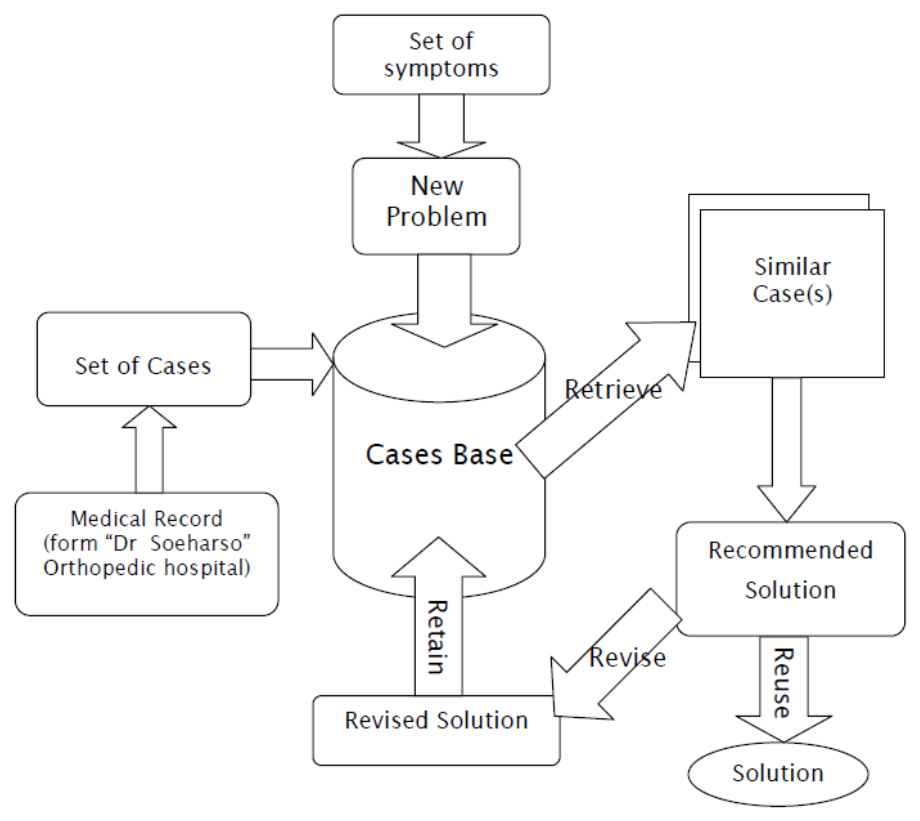

Figure 2: general description

As it was describing before, the retrieval case process calculates the level of case similarity between a new problem with all cases on the case-based. Whereas, the calculation of the level of case similarity between cases will be conducted in as it follows:

Let $X\left(x_{1}, x_{2}, x_{3}, \ldots, x_{m}\right)$ is input case given by user, and $Y\left(y_{1}, y_{2}, y_{3}, \ldots, y_{m}\right)$ is a target case in the case-base and $W\left(w_{1}, w_{2}, w_{3}, \ldots, w_{m}\right)$ is weight coefficient from the attributes of cases that satisfies $0 \leq w_{i} \leq 1 \quad(i=1,2,3, \ldots, m)$ dan $\sum_{i=1}^{m} w_{i}=1$.

$\operatorname{Sim}\left(x_{i}, y_{i}\right)$ represents a function of similarity between the attributes $i$ of $\mathrm{X}$ and the attributes $i$ of $\mathrm{Y}$ which has the real number in the interval $[0,1]$. Assume that each of the attribute is given the weight $w_{i}$, the degree of similarity between input case and the targeted case is given by $\operatorname{Sim}(X, Y)$ which is formulated as it follows:

$$
\operatorname{Sim}(X, Y)=\sum_{i=1}^{m} w_{i} \times \operatorname{Sim}\left(x_{i}, y_{i}\right)
$$

The next is the calculation of $\operatorname{Sim}\left(x_{i}, y_{i}\right)$ will be carried on considering the value types from the case attributes. The calculation method will be shown below [10]:

1. The attribute value in the form of symbol (figure, string):

$$
\operatorname{Sim}(a, b)=\left\{\begin{array}{l}
1, a=b \\
0, a \neq b
\end{array}\right.
$$

The attribute value in numerical form: 


$$
\operatorname{Sim}(a, b)=1-\frac{|b-a|}{B-A} \quad a, b \in[A, B]
$$

With $\mathrm{A}$ and $\mathrm{B}$ are lower and upper bound of interval $(\mathrm{A} \neq \mathrm{B})$

2. The attribute value in interval form:

To calculate the degree of similarity from the attributes which has interval value can be formulated as it follows:

$$
\begin{array}{r}
\operatorname{Sim}\left(\left[b_{1}, b_{2}\right], a\right)=\int_{b_{1}}^{b_{2}} \operatorname{Sim}(a, x) f(x) d x \\
a, b_{1}, b_{2} \in[A, B]
\end{array}
$$

where A and B are the lower and upper bound of interval that contain $\mathrm{a}, \mathrm{b}_{1}, \mathrm{~b}_{2}$. $\operatorname{Sim}(a, b)$ can be calculated based on the equation (3), while $\int f(x)$ shows the probability value of $\mathrm{x}$ at interval $\left(\mathrm{b}_{1}, \mathrm{~b}_{2}\right)$ that meets $\int_{b_{1}}^{b_{2}} f(x) d x=1$. Generally, this value $f(x)$ is given based on statistical data or expert's authority. If the probability from each value of the attributes is same in the interval, then $f(x)=1 / b_{2}-b_{1}$.

\section{RESULTS AND DISCUSSION}

a. The Formation of case-based.

Based on the medical record of patients in emergency unit at "Dr. Soeharso" hospital in Surakarta, one case will represent in various features, namely: age, sex, educational background, blood pressure, pulse rate for minute, respiratory (the number of haling per minute), $\mathrm{SPO}_{2}$ (the oxygen level in the blood), the painful scale, the medical diagnostics, psychological diagnostic and the psychological therapy. In this research, one case will be represented at one frame as it shows in Figure 3.

\begin{tabular}{|ll|}
\hline Nama & $:$ (name of patient) \\
Umur & $:$ (age of patient) \\
Jenis Kelamin & $:$ (male/female) \\
Pendidikan & $:$ (based on the patient's background of \\
& education) \\
Tensi & $:($ blood pressure $)$ \\
Nadi & $:$ (pulse rate per minute) \\
Respirasi & $:$ (the amount of respiration per minute) \\
SPO2 & $:($ the oxygen level in the blood) \\
Skala Nyeri & $:$ (based on the patient's feel towards pain \\
& scale) \\
Dx_Medis & $:($ medical diagnosis) \\
Dx_Psikologi & $:$ (psychological diagnosis) \\
\hline
\end{tabular}

Figure-3: a case representation

the features in that case consist of three features which can be categorized as string, namely Jkel, Dx_Medis dan Dx_Psi, and seven features which are typed numeric. Particularly, in feature of educational background, the numeric given by changing the order education 
(primary school $=1$, elementary school $=2$ and so on). Furthermore, a case will be saved in the data record structures, which contain various features, as it follows:

(umur, jkel, pend, tensi, nadi, resp, SPO, nyeri, dx_medis, dx_psi, Th_psi)

In this research, each feature will be given the equal weight. Some examples of cases will be shown in table-1.

Table-1 : samples of base case

\begin{tabular}{|l|c|c|c|c|c|c|c|c|c|l|l|l|}
\hline \multirow{2}{*}{ No } & \multirow{2}{*}{ umur } & \multirow{2}{*}{ Jkel } & \multirow{2}{*}{ Pend } & \multicolumn{2}{|c|}{ Tensi } & \multirow{2}{*}{ nadi } & resp & SPO & nyeri & Dx_medis & Dx_Psi & Therapi_Psi \\
\hline 1. & 39 & L & SMA & 112 & 79 & 89 & 20 & 100 & 5 & $\begin{array}{l}\text { OF.TIBA } \\
\text { PLATEU D }\end{array}$ & CEMAS & ASS \\
\hline 2. & 51 & L & SMA & 159 & 105 & 100 & 24 & 99 & 6 & $\begin{array}{l}\text { CF.ACETAB } \\
\text { ULUM D }\end{array}$ & CEMAS & ASS \\
\hline 3. & 56 & L & SMA & 180 & 104 & 100 & 24 & 100 & 5 & $\begin{array}{l}\text { CF.CLAVIC } \\
\text { ULLA D }\end{array}$ & $\begin{array}{l}\text { MOOD DISORD } \\
\text { ER }\end{array}$ & $\begin{array}{l}\text { ASS. } \\
\text { PSIKIATER }\end{array}$ \\
\hline 4. & 53 & L & SD & 113 & 70 & 87 & 20 & 99 & 7 & $\begin{array}{l}\text { CF.FIBULA } \\
\text { DNG }\end{array}$ & CEMALOVING & ASS \\
\hline 5. & 32 & L & SMA & 117 & 72 & 92 & 24 & 100 & 7 & $\begin{array}{l}\text { INTERCON } \\
\text { DYLER } \\
\text { FEMUR S }\end{array}$ & CEMAS & ASS, KONS \\
\hline 6. & 14 & L & SMP & 114 & 67 & 96 & 20 & 100 & 6 & $\begin{array}{l}\text { CF. RADIUS } \\
\text { ULNA S }\end{array}$ & $\begin{array}{l}\text { DEPRES } \\
\text { I }\end{array}$ & ASS \\
\hline$:$ & $:$ & $:$ & $:$ & $:$ & $:$ & $:$ & $:$ & $:$ & $:$ & $\begin{array}{l}: \\
:\end{array}$ \\
\hline 34 & 48 & L & SMA & 135 & 89 & 100 & 24 & 98 & 3 & $\begin{array}{l}\text { OSTEOMILI } \\
\text { TIS FEMUR }\end{array}$ & CEMAS & ASS \\
\hline
\end{tabular}

b. System Implementation

In implementing this CBR system, initially it was found 34 cases. The preliminary consult process will be shown in Figure 4.

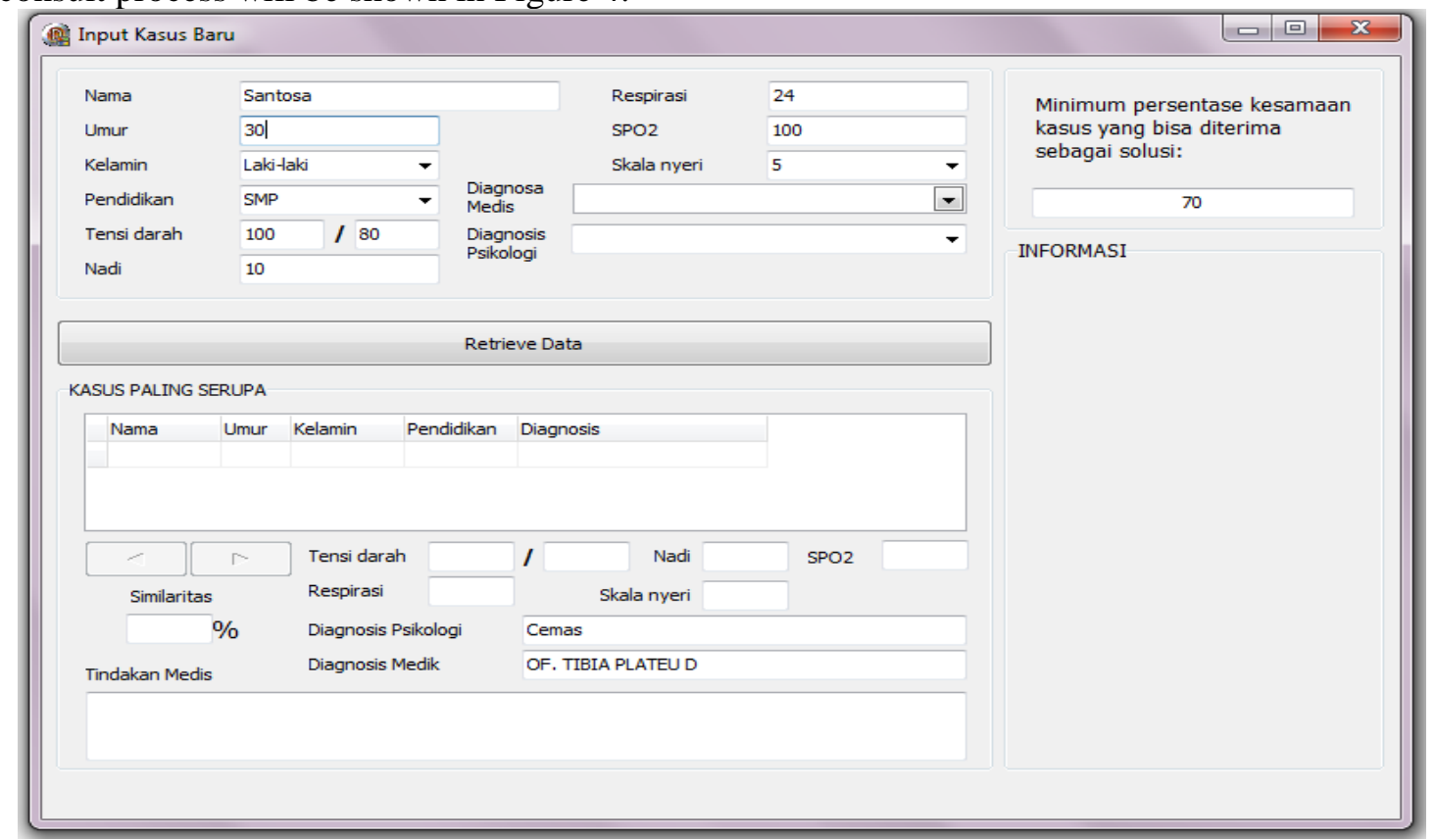

Figure-4: Preliminary of Consult Form

Through the form, the user can insert a new case, which the condition or symptoms suffered by the patients.

IJCCS Vol. 12, No. 1, January 2018: $11-20$ 


\section{Test 1:}

For instance, the data was filled in:

$\begin{array}{ll}\text { Nama } & : \text { Santosa } \\ \text { Umur } & : 30 \text { tahun } \\ \text { Jenis Kelamin } & : \text { Laki-laki } \\ \text { Pendidikan } & : \text { SMP } \\ \text { Tensi } & : 100 / 80 \\ \text { Nadi } & : 10 \\ \text { Respirasi }: 24 & \\ \text { SPO2 } & : 100 \\ \text { Skala Nyeri } & : 5 \\ \text { Dx_Medis } & : \text { CF CLAFICULLA D } \\ \text { Dx_Psikologi } & : \text { Depresi Berat }\end{array}$

Before finding the solution, the user has to fill out the threshold value wanted. In this example has been filled in the threshold value: 75 which means only three cases having the degree of similarity more than $75 \%$ were shown. After retrieving all processes, the results will be shown in Figure 5.

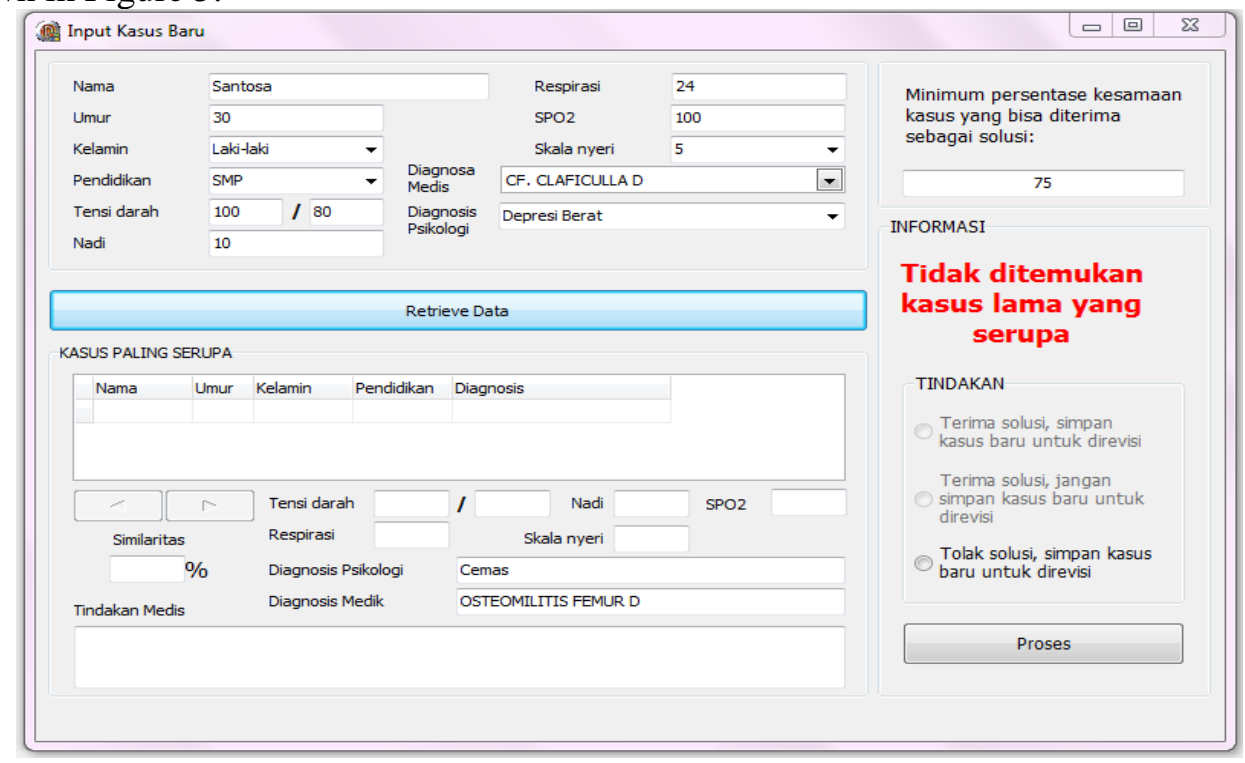

Figure-5: The result from test-1

The display from test 1 in Figure 5 shows that it can't be found the case which has the degree of similarity higher than $75 \%$. In the other words, no similar case towards that case.

\section{Test -2 :}

For instance, it was filled in below:

$\begin{array}{ll}\text { Nama } & : \text { Santosa } \\ \text { Umur } & : 45 \text { tahun } \\ \text { Jenis Kelamin } & : \text { Laki-laki } \\ \text { Pendidikan } & : \text { SMP } \\ \text { Tensi } & : 120 / 90 \\ \text { Nadi } & : 60 \\ \text { Respirasi : 45 } & \\ \text { SPO2 } & : 98 \\ \text { Skala Nyeri } & : 5 \text { (pilihan) } \\ \text { Dx_Medis } & : \text { CF CLAFICULLA D } \\ \text { Dx_Psikologi } & : \text { Cemas } \\ \text { Nilai ambang } & : 50\end{array}$


Having retrieved data, so the results has been found as it shows in Figure-6

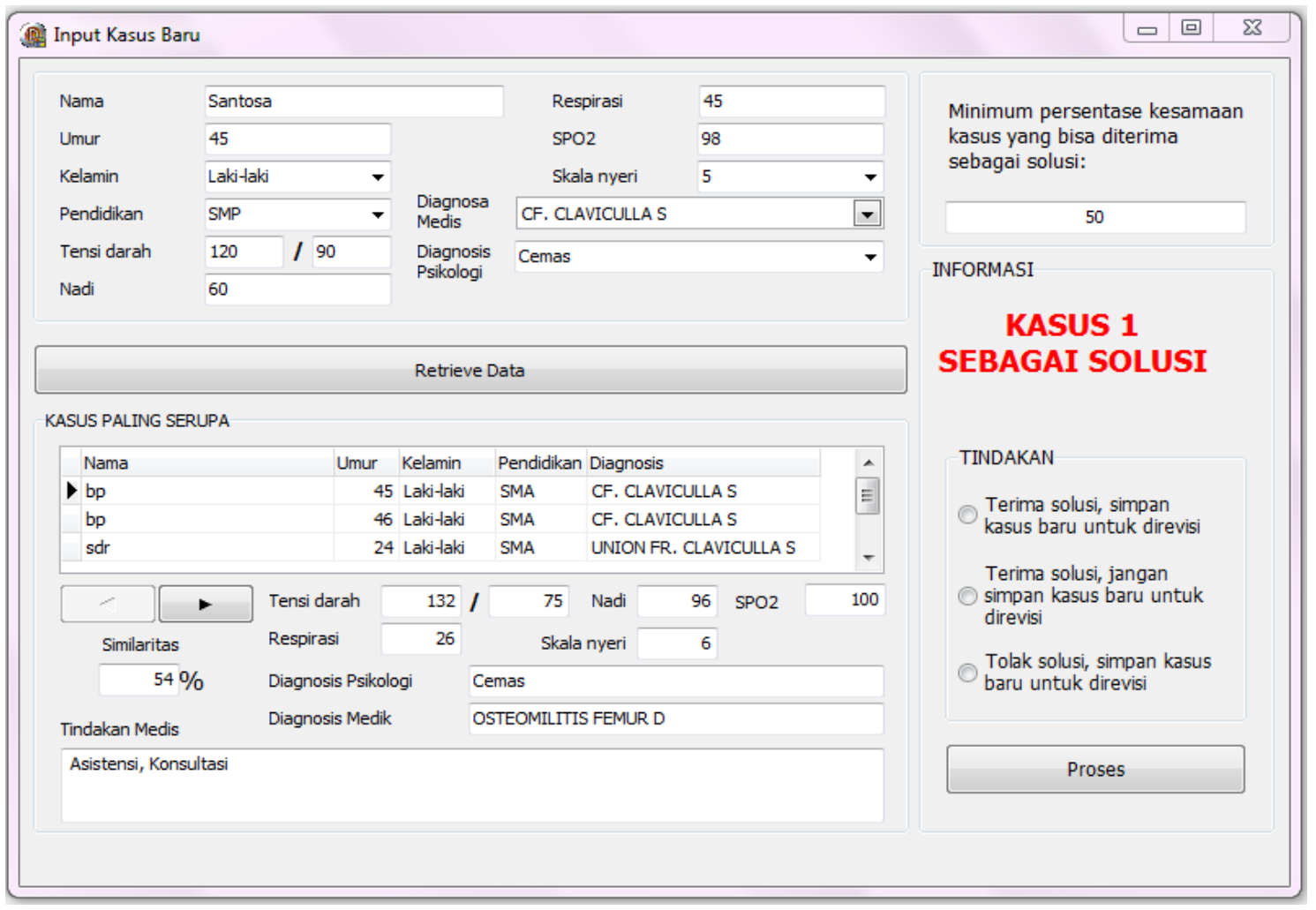

Figure-6: Result of test -2

Based on the test-2, it can be known that the three cases found which are higher similarity than $50 \%$. With the given threshold before, the psychological therapy suggested is to give assistance and consult. Nevertheless, that solution could not be effectively seen because the similarity was $54 \%$.

\section{Test -3 :}

For instance, it was filled in below:

$\begin{array}{ll}\text { Nama } & : \text { Santosa } \\ \text { Umur } & : 45 \text { tahun } \\ \text { Jenis Kelamin } & : \text { Laki-laki } \\ \text { Pendidikan } & : \text { SMP } \\ \text { Tensi } & : 130 / 80 \\ \text { Nadi } & : 95 \\ \text { Respirasi : 25 } & \\ \text { SPO2 } & : 98 \\ \text { Skala Nyeri } & : 6 \text { (pilihan) } \\ \text { Dx_Medis } & : \text { OSTEOMILITIS FEMUR D } \\ \text { Dx_Psikologi } & : \text { Cemas } \\ \text { Nilai ambang } & : 85\end{array}$

Having retrieved data, so the results has been found as it shows in Figure-7 


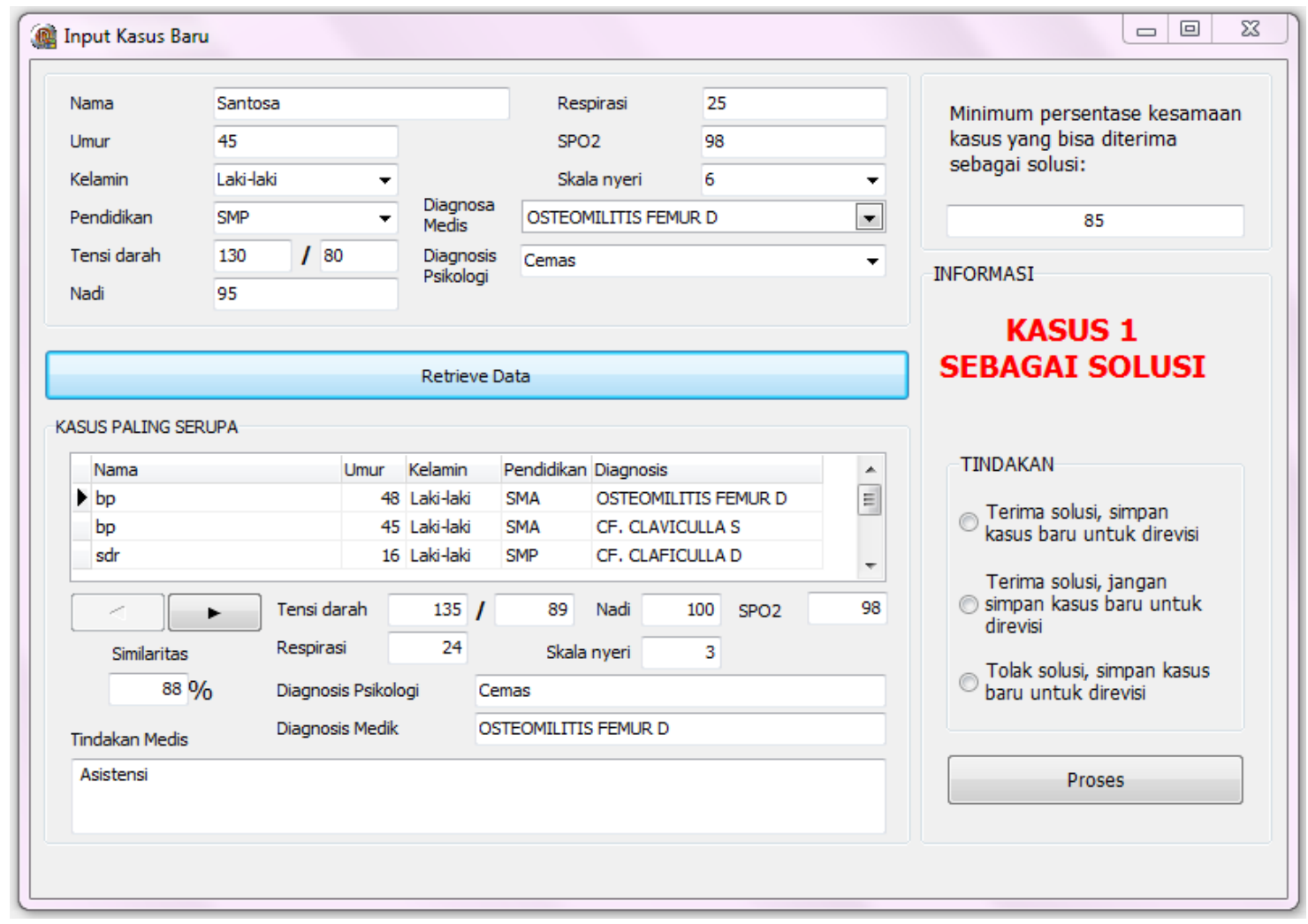

Figure-7: Results of test-7

Based on the test-3, it can be known that the three cases found which are higher similarity than $85 \%$. With the given threshold before, the psychological therapy suggested is to give assistance. And then, one of the three cases can be selected to provide, namely: receiving the psychological therapy solution which was recommended and retrieved directly (added in any case bases), receiving the recommended solution, however, it is not directly retrieved till it has been revised by the expert or refuse (do not use) the recommended solution.

The system examines ten new problems that the results should be confirmed by psychologist. By giving threshold 50\%, furthermore, there are six results found. This means that the research studied shows the accuracy $60 \%$.

\section{CONCLUSION}

Based on the development of computerizing a case-based reasoning to determine the action of the psychological therapy for the patients in Post-accident, it can be concluded that the system selects and determines any cases which have the higher degree of similarity and threshold given, as it is the recommendation of the psychological therapy treatment. Based on the test conducted, CBR system which is developed, it gives the accuracy $60 \%$ in threshold $50 \%$. This shows that the system has yet to give a good accuracy considering there were only 34 cases that were been catalogued. 


\section{ACKNOWLEDGEMENT}

This research is funded by BPPTNBH grant at Faculty of Mathematics and Natural Sciences, Universitas Gadjah Mada with No. 0059/J01.1.28/PL.06.02/2016.

\section{REFERENCES}

[1] A. Aamold, and E. Plaza, "Case-based Reasoning : Foundation issues, methodological variation and System approach", AI Communication 7(1), pp. 39-59, 1994.

[2] M. Denis, dan A. Jasmin, Applying Case-based reasoning for mobile support in diagnosing infective diseases. International Conference on Signal Processing Systems, IEEE Computer Society. 779-783, 2009.

[3] B. Chakraborty, I. Srinivas, P. Sood, V. Nabhi, D. Ghosh, "Case Based Reasoning Methodology for Diagnosis of Swine Flu", IEEE GCC Confererence and Exhibition, 19-22 Februari 2011, Dubai, United Arab Emirates, pp. 132-135, 2011

[4] P.P.S. Tomar, R. Singh, P.K. Saxena, and J. Sharma, "Case Based Medical Diagnosis of Occupational Chronic Lung Diseases From Their Symptoms and Signs", International Journal of Biometrics and Bioinformatics (IJBB), Vol. (5) : Issue (4), pp. 216-224, 2011

[5] S. Pant and S. R. Joshi, "Case-Based Reasoning In Neurological Domain", IEEE 978-1$4673-2590-5 / 12,2012$

[6] K. Ghorai, S. Saha, A. Bakshi, A. Mahanti, P. Ray, "An mHealth Recom-mender for Smoking Cessation using Case Based Reasoning", 46th Hawaii International Conference on System Sciences, pp. 2695-2704, 2013

[7] S. Mulyana, S. Hartati, R. Wardoyo and E. Winarko, " Case-based Reasoning with Input Text Processing to Diagnose Mood [Affective]Disorders", International Journal of Advanced Research in Artificial Intelligence(IJARAI),Vol. 4, No.9, pp. 1-5 , 2015

[8] E. Wahyudi and S. Hartati, "Case-Based Reasoning untuk Diagnosis Penyakit Jantung", Indonesian Journal of Computing and Cybernetic Systems, Vol. 11, No. 1, pp. 1-10 , 2017

[9] S. Mulyana , S. Hartati., R. Wardoyo and E.Winarko, "Case-based Reasoning for Selecting Study Program in Senior Hight School", International Journal of Advanced Computer Science and Applications (IJACSA),Vol. 6, Issue. 9, pp. 136-140 , 2015

[10] Y. Minghai, and X. Huanmin, "The weight calculation in the case-based reasoning based on sensitivity analysis", International Conference on Electrical and Control Engineering, pp. 3119-3121. 978-0-7695-4031-3/10 (C) 2010 IEEE, DOI 10.1109/iCECE.2010.761, 2010 